\title{
Mycobacteriosis in wild rabbitfish Siganus rivulatus associated with cage farming in the Gulf of Eilat, Red Sea
}

\author{
A. Diamant*, A. Banet, M. Ucko, A. Colorni, W. Knibb, H. Kvitt \\ Israel Oceanographic and Limnological Research, National Center for Mariculture, PO Box 1212, Eilat 88112, Israel
}

\begin{abstract}
Infection patterns of Mycobacterium marinum were studied over a period of 3 yr in wild rabbitfish Siganus rivulatus populations associated with commercial mariculture cages and inhabiting various sites along the Israeli Red Sea coastline. Mycobacteriosis was first recorded from the Red Sea in 1990 in farmed sea bass Dicentrarchus labrax and is absent from records of studies on parasites and diseases of wild rabbitfish carried out in the 1970 s and 1980s. A sharp increase in the prevalence of the disease in cultured and wild fish in the region has occurred since. A total of 1142 rabbitfish were examined over a 3 yr period from inside mariculture net cages, from the cage surroundings and from several sites along the coast. Histological sections of spleens were examined for presence of granulomatous lesions. Overall prevalence levels of $50 \%$ were recorded in the rabbitfish sampled inside the net cages and $39 \%$ at the cages' close surroundings, $21 \%$ at a sandy beach site $1.2 \mathrm{~km}$ westwards, $35 \%$ at Eilat harbour $3 \mathrm{~km}$ to the south and $42 \%$ at a coral reef site about $10 \mathrm{~km}$ south of the cages. In addition, 147 fish belonging to 18 native Red Sea species were sampled from 2 sites, the net cage farm perimeter and the coral reef area, and examined for similar lesions. None of those from the coral reef were infected with Mycobacterium; however, 9 of 14 species collected from the cage surroundings were infected. An increase in prevalence of mycobacteriosis in the mariculture farm area was noted from 1995 to 1997. At the same time, a significant increase in prevalence was also apparent at the coral reef sampling site. Two $M$. marinum isolates from rabbitfish captured at Eilat harbour and the coral reef site were shown by $16 \mathrm{~S}$ rDNA sequencing analysis to be identical to isolates from rabbitfish trapped inside the mariculture cages as well as isolates from locally cultured sea bass $D$. labrax. The implications of spreading of $M$. marinum infection in wild fish populations in the Gulf of Eilat are discussed.
\end{abstract}

KEY WORDS: Mycobacterium marinum - Spleen - Granuloma - Fish disease - 16S rDNA sequence . Coral reef - Sea cages - Mariculture

\section{INTRODUCTION}

The rapid development of marine fish and shellfish farming in the last decade has raised worldwide concern with regard to the impact of their waste products - nutrients, chemicals and veterinary pharmaceuticals, to name a few - on coastal ecosystems. There is a growing body of evidence that mariculture activities alter the coastal ecosystem by enhancing the development of antibiotic-resistant pathogens, modifying microbial dynamics, affecting predator-prey relationships,

•E-mail: diamant@agri.huji.ac.il linking with harmful algal blooms and even adversely affecting public health (Gowen \& Bradbury 1987, Aure \& Stigebrandt 1990, Iwama 1991, McVicar 1997b).

Sea-caged fish interact with local wild fish communities through access of free ranging, feral animals into the net cages and/or farmed fish that escape into the surrounding ecosystem (Egidius et al. 1983, McVicar 1997a). The convergence of farm escapees and wild fish around cages is a well known phenomenon which causes concern due to possible genetic alteration of wild populations, attraction of predators to the farmed stocks and formation of vector reservoirs for disease transmission (Carss 1990, McVicar 1997a,b). Gill, skin and alimentary tract lesions are a source for pathogen 
shedding into the water, hereby spreading the infection to other fish (Munro et al. 1983, Belas et al. 1995). Both cultured and wild fish are constantly exposed to freshly released or excreted infectious material, which increases the probability for disease transmission.

Conversely, numerous disease outbreaks in fish farms have been linked in the past to sources of infection from the surrounding environment (Munro et al 1983, Silan et al. 1985, McArdle et al. 1993, Kent 1994, Diamant \& Paperna 1995, McVicar 1997 a,b, Kent et al 1998). The high cage-stocking densities may enhance levels of indigenous, enzootic diseases in wild populations and greatly modify patterns of occurrence, prevalence or pathogenicity in a given area (Stephen et al. 1993, McVicar 1997b, Gonzalez 1998).

Mariculture of translocated stocks or exotic species increases the risk of introduction of disease agents to new areas, with potentially grave consequences to local fishes (McVicar 1975). Exotic pathogens originating in cage-farmed fish may establish self-perpetuating reservoirs in cohabiting wild fish populations (Munro et al. 1983, Treasurer \& Cox 1991, Treasurer \& Laidler 1994, Paperna in press). One of the most serious arguments against fish farming is that accidental liberation of fish, or discharge of untreated water in which they were kept, may promote diseases in the natural environment (Coutant 1998)

In the northern Gulf of Eilat (Red Sea), 2 commercial farms have operated for several years, presently encompassing a total of $>60$ floating cages that generate the bulk of the current mariculture production in Israel (approximately 1200 tons; Mires 1997). Popper (1995) and Porter et al. (1996) have described some of the environmental effects of these farms.

Gilt-head sea bream Sparus aurata (Sparidae), a Mediterranean species, is the main fish cultured in the net cage farms in Eilat. Additional species previously or presently cultured include European sea bass Dicentrarchus labrax (Serranidae), red sea bream Pagrus major (from Japan), and Diplodus puntazzo and D. sargus (Mediterranean) (Sparidae) (Kissil 1996). European sea bass was long considered a high-potential candidate for large-scale cage culture in Israel, but problems with Mycobacterium marinum infections have seriously hampered commercial farming of this species (Colorni 1992, Colorni et al. 1996). Nevertheless, sea bass stocks have been frequently held in the net cages in Eilat and Mycobacterium species infections have been repeatedly diagnosed in them (Diamant \& Colorni 1995 and unpubl. data). A recent addition at the cage site is the red drum Sciaenops ocellatus, a species introduced from the U.S., which also displays high susceptibility to mycobacteriosis and develops severe visceral and integumental lesions (Diamant \& Colorni unpubl, data)
The mariculture cage farms in Eilat are a point of convergence for large numbers of wild fish, with one of the most common being the rabbitfish Siganus rivulatus. Fish are thought to be attracted by the semisheltered cage structures and continuous supply of feed at aquaculture operations (Egidius et al. 1983, Carss 1990). Small-sized fish easily pass through cage meshes and mingle with the farmed stocks. Some, like juvenile rabbitfish, rapidly outgrow the mesh size and remain trapped inside the cages. Mycobacterium marinum infections have been found in such cageentrapped rabbitfish (Diamant \& Colorni 1995).

In the present study, we investigated Mycobacterium marinum infection patterns in wild Red Sea fish populations, both of fish aggregating at the mariculture cage farms, and of fish inhabiting various sites along the Israeli Red Sea coastline.

\section{MATERIALS AND METHODS}

Study area. The commercial mariculture cages (sampling site ARC) are located 300 to $600 \mathrm{~m}$ off Eilat's North Beach (Fig. 1) moored above a wide flat, sandy sea bed which comprises the natural nursery ground for many native fish species later associated with the coral reef as adults (Fishelson 1977, Golani 1993).

The other sampling sites were as follows: the mariculture cages' close surroundings (AR), a sandy beach

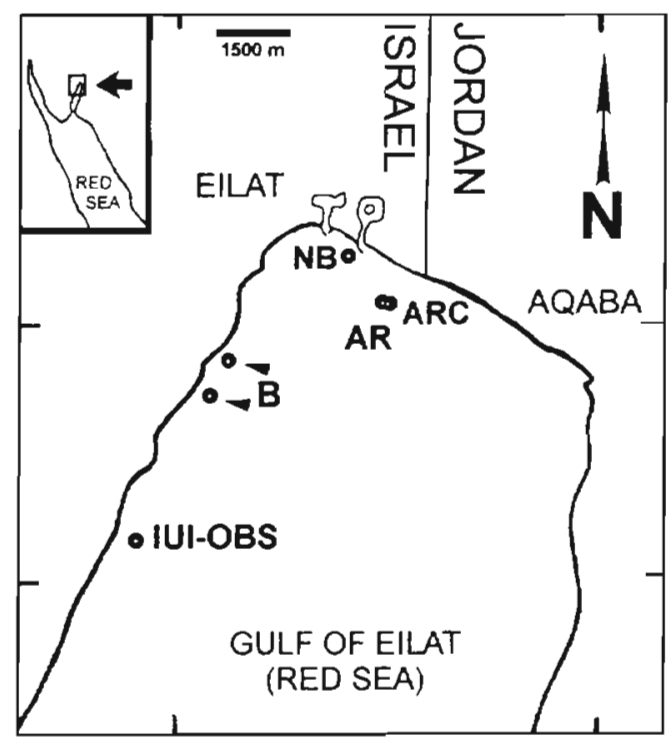

Fig. 1. Map of the study area, northern Gulf of Eilat, Red Sea, with the sampling sites ARC (mariculture cages), AR (outside the cages), NB (North Beach), B (Eilat harbour area) and IUIOBS (Inter-University Institute and Underwater Observatory coral reef site) 
site $1.2 \mathrm{~km}$ west of the farm site (NB), the Eilat harbour area approximately $3 \mathrm{~km}$ to the south (B), and a coral reef site, near the Interuniversity Institute and Coral World Underwater Observatory (IUI-OBS), about $10 \mathrm{~km}$ south of the cages (Fig. 1).

Samples of rabbitfish. Monthly samples of rabbitfish were obtained from inside the net cages between December 1994 and December 1997, totaling 583 fish. The fish were either acquired from the mariculture cages upon harvest of stocks for marketing, or captured with dipnet. An additional 559 rabbitfish were sampled from the area around the cages and sampling sites along the Eilat coastline from November 1995 until December 1997, as part of a study of the parasitic infections of rabbitfish in the region (Diamant et al. 1999). Baited wire-mesh traps were placed at depths of 2 to $14 \mathrm{~m}$ and left for 24 to $48 \mathrm{~h}$. Fish caught in these traps were transferred live to the laboratory, where they were maintained in a flow-through sea water system, killed and dissected within 48 to 72 h of capture. Fish obtained from inside the net cages were received freshly dead (iced) and processed immediately. Since the spleen has been shown to be a good representative organ for diagnosis of the disease in fish (Colorni 1992, Colorni et al. 1996, 1998), the spleens of all collected fish were removed and fixed for histological processing. Various additional tissues (e.g. gills, liver, kidney and intestine) were also sampled and examined in some cases.

Other fish species caught near the cage farms, as well as fish collected at a coral reef site just south the IUI-OBS sampling site in June 1997 following an accidental insecticide poisoning, were also examined for splenic granulomata (see Table 1).

Histology, bacteriology and statistical analysis. Altogether, a total of 1142 rabbitfish measuring 125 to $270 \mathrm{~mm}$ (FL) and an additional 148 specimens belonging to 18 other species from the various sampling sites were examined histologically for splenic granulomatous lesions and acid-fast rod-shaped bacteria. Spleens were fixed with buffered neutral formalin, dehydrated in a graded ethanol series and embedded in either paraffin or glycol methacrylate blocks. Sections were stained with Ziehl-Neelsen (Z-N).

Infections in the sampled fish were recorded as presence of splenic granulomata in the histological sections per individual fish. One random spleen section from each fish was carefully inspected at $\times 400$ and $\times 1000$ (oil immersion) under an Olympus BF-2 compound microscope. Each sample received a score of nil (uninfected) or a ' + ' (presence of at least 1 granuloma with visible acid-fast bacteria, regardless of the lesion stage of development or number of granulomata per spleen section).

A correlation analysis of fish length with infection was carried out by computing prevalence in each of 51 groups of 10 fish of similar length, which were randomly selected from the combined rabbitfish samples. Data were analyzed for 2 periods: the first 18 mo (1995-96) versus the last 18 mo (1996-97). KruskalWallis ANOVA, Mann Whitney $U$-test and TukeyKramer multiple comparison test for unequal sample sizes were employed to compare differences in mean prevalence of infection between sites and per site over time. All data were compiled and sorted using Microsoft Excel $^{\circledR}$. The statistical analyses were carried out with a $\mathrm{JMP}^{\oplus}$ Statistical Package for PC.

In representative cases, fresh smears were taken from suspected spleens, air-dried, fixed and stained with Z-N for presence of acid-fast bacteria. Bacterial cultures were grown from suspected spleen samples on Loewenstein-Jensen medium and the isolates were biochemically identified by their characteristic attributes as described by Colorni (1992). Molecular identification of isolates was carried out by sequencing a 600 bp fragment of $16 \mathrm{~S}$ rDNA PCR product, as previously described in Knibb et al. (1993).

Table 1. List of wild Red Sea fish species examined for Mycobacterium marinum infections at sites AR and south of IUI-OBS

\begin{tabular}{|llcc|}
\hline Site and species & Family & No. & $\begin{array}{c}\text { M. marinum- } \\
\text { infected }\end{array}$ \\
\hline Mariculture net cage farm area (AR site) & & \\
Athernomorus lacunosus & Atherinidae & 30 & $1 / 30$ \\
Decapterus russelli & Carangidae & 20 & $1 / 20$ \\
Trachurus indicus & & 8 & $1 / 8$ \\
Scomber australicatus & Scombridae & 4 & 0 \\
Abudefduf saxatilis & Pomacentridae & 3 & 0 \\
Pomacentrus myriae & & 11 & $2 / 11$ \\
Acanthopagrus bifasciatus & Sparidae & 5 & $2 / 5$ \\
Diplodus noct & & 1 & $1 / 1$ \\
Pterois miles & Scorpaenidae & 1 & 0 \\
Siganus luridus & Siganidae & 5 & $2 / 5$ \\
Scarus sp. & Scaridae & 2 & 0 \\
Thalassoma sp. & Labridae & 2 & 0 \\
Mugil & Mugilidae & 3 & $1 / 3$ \\
Kiphosus cinereus & Kiphosidae & 3 & $2 / 3$ \\
& & & \\
Coral reef (south of IUI-OBS site) & & 0 \\
Dascyllus trimaculatus & Pomacentridae & 29 & 0 \\
Abudefduf saxatilis & & 3 & 0 \\
Diplodus noct & Sparidae & 11 & 0 \\
Scarus sp. & Scaridae & 4 & 0 \\
Thalassoma klunzingeri & Labridae & 2 & 0 \\
Epinephelus fasciatus & Serranidae & 1 & \\
\hline
\end{tabular}




\section{RESULTS}

The rabbitfish sampled from all sites had no external lesions and appeared clinically normal. Upon dissection and examination of the viscera, the spleen was in many cases moderately enlarged and contained whitish-yellow nodules in which acid-fast rods were evident in air-dried, stained smears. Cases of extreme splenomegaly, such as those found in sea bass (Colorni 1992), were not found. Heavily infected rabbitfish displayed also whitish-yellow nodules in the liver, kidney, alimentary tract and mesenteries.

Splenic pathology in the rabbitfish ranged from few, scattered granulomata at various stages of development, to massive involvement with multi-focal, coalescing foci, some containing dense cores of necrotic debris (Fig. 2). The acidfast bacteria could be clearly discerned in the Z-N stained histological sections; while some were concentrated in dense pockets in the core area, others were loosely dispersed at the granulomata periphery (Fig. 3).

The length/infection-prevalence analysis of 51 groups of 10 fish of similar lengths produced a highly significant correlation ( $p>0.0001)$ between mean infection prevalence with Mycobacterium marinum and fish length (Fig. 4)

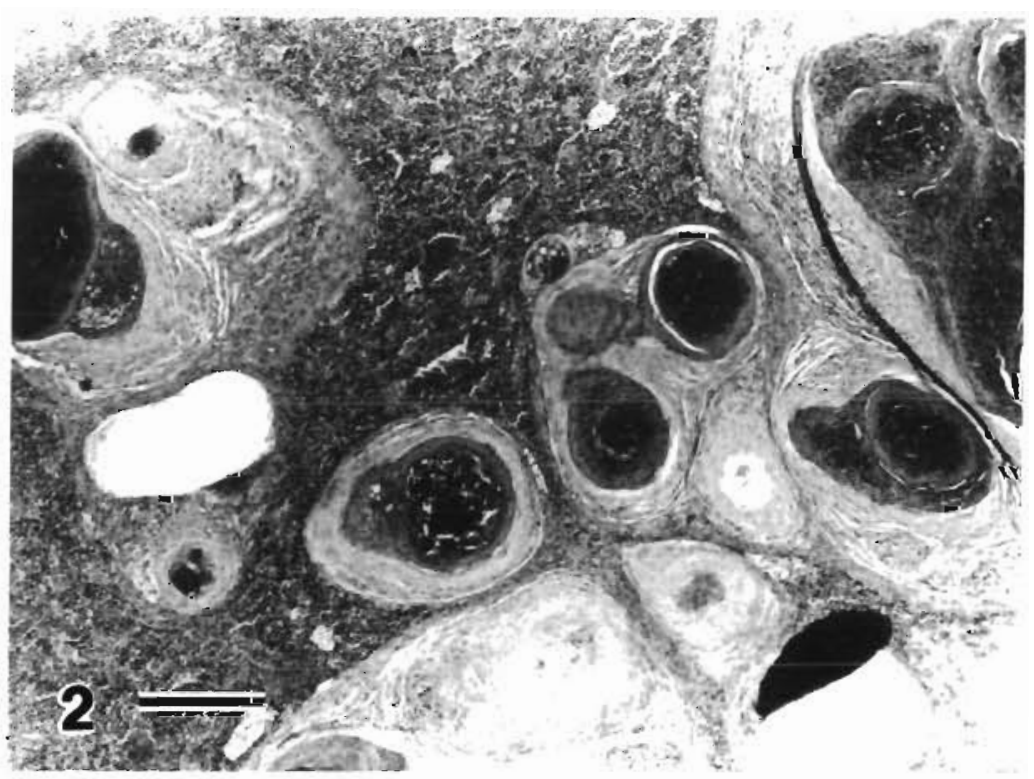

Fig. 2. Histological section of spleen from rabibitfish Siganus rivulatus caught at IUI-OBS coral reef sampling site, displaying numerous granulomata (Ziel-Neelsen, scale bar $=200 \mu \mathrm{m})$
Histological analyses revealed bacterial lesions in 31 to $86 \%$ of the rabbitfish monthly samples collected inside the cages (ARC) (Fig. 5). The overall prevalence of infection of all sampling sites is given in Table 2.

A comparison of the prevalence of Mycobacterium marinum infections in the rabbitfish samples between the periods $1995-96$ and $1996-97$ is shown in Fig. 6. When considering differences over time inside the cages, mean prevalence did not change significantly and remained high throughout the study (around $50 \%$ ). Similarly, no significant fluctuations were evident at sites AR (cage periphery) and B (Eilat harbour area). A noticeable change, however, was seen at the IUI-OBS coral reef site, which displayed a sharp (highly significant) increase in prevalence from $34 \%$ in $1995-96$ to $66 \%$ in 1996-97. North Beach (NB) rabbitfish displayed a significant decrease in prevalence in 1996-97, but this was probably due to the sampling artifact (see 'Discussion'). When considering differences between sites, prevalence was significantly higher in rabbitfish in the cages during 1995-96 when compared to free-ranging fish outside the cages. The same pattern persisted during 1996-97.

Mycobacteria were isolated from spleen of rabbitfish from 2 sites, Site B and Site IUI-OBS. The rDNA sequence analyses of the 2 isolates (Fig. 7) indicated they were identical to the strain of 


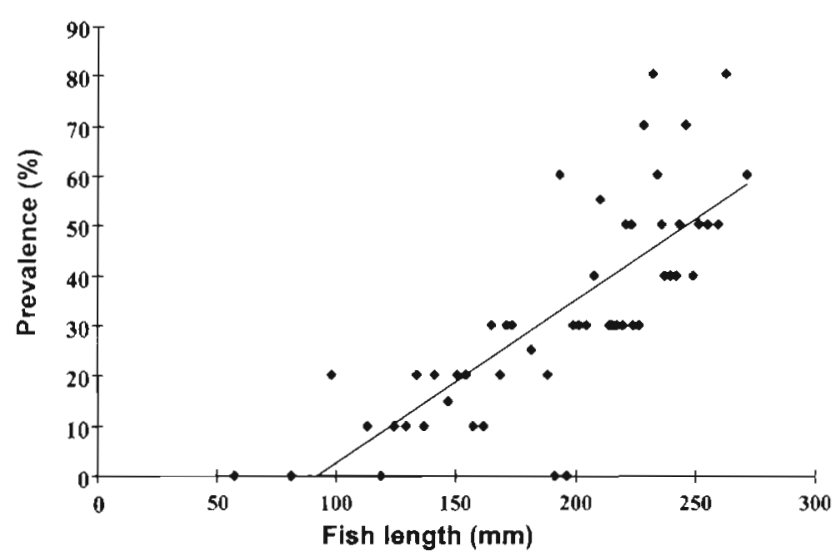

Fig. 4. Correlation between prevalence of Mycobacterium marinum infection and rabbitfish fork length (FL) per 51 length groups of 10 fish $(n=510) ; y=0.0032 x-1.2961$; $\mathrm{R}^{2}=0.6083 ; \mathrm{p}<0.001$

Mycobacterium marinum previously isolated from cultured sea bass (Knibb et al. 1993).

\section{DISCUSSION}

The first case of mycobacteriosis in the Red Sea was diagnosed in 1990 in cultured sea bass Dicentrarchus labrax in Eilat (Colorni 1992). The species was subsequently identified by Knibb et al. (1993) as Mycobacterium marinum by molecular comparison, using PCR and direct sequencing of ribosomal encoding DNA (16S rDNA) analysis of approximately 600 base pairs. The same pathogen was later found in 16 different species of captive marine fish, with all isolates identified as belonging to a single strain of $M$. marinum (Colorni et al. 1996 and unpubl. data). At the same time, Mycobacterium isolates from cultured $D$. labrax in Greece, Belgium and Denmark were identified as different strains of $M$. marinum, suggesting that however 'ubiquitous' this bacterium seems to be, endemic strains occur in different geographic localities.

Table 2. Occurrence of Mycobacterium marinum in collected samples of caged-captive and wild rabbitfish Siganus rivulatus in the present study, as determined by presence of acid-fast bacteria in splenic granulomata

\begin{tabular}{|lrr|}
\hline Site & $\begin{array}{c}\text { Sample } \\
\text { size }\end{array}$ & $\begin{array}{c}\text { No. of hosts } \\
\text { infected (\%) }\end{array}$ \\
\hline ARC (inside mariculture cages) & 583 & $292(50.0)$ \\
AR (outside mariculture cages) & 166 & $53(31.9)$ \\
NB (North Beach) & 215 & $46(21.4)$ \\
B (Eilat harbour area) & 49 & $17(34.7)$ \\
IUI-OBS (coral reef at Inter-University & & \\
$\quad$ Institute/Underwater Observatory) & 129 & $54(41.9)$ \\
Total & 1142 & $462(40.5)$ \\
\hline
\end{tabular}

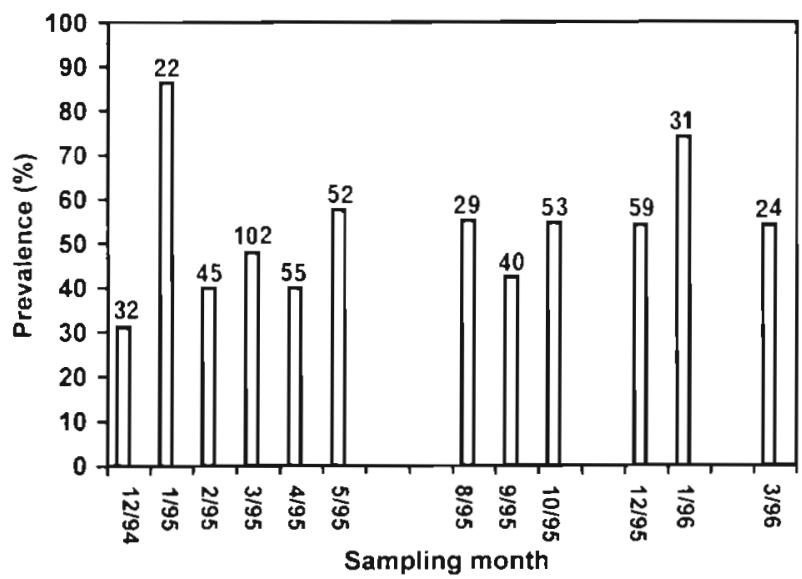

Fig. 5. Prevalence of Mycobacterium marinum in monthly samples of rabbitfish Siganus rivulatus from the mariculture site (ARC). These samples were examined in stocks harvested from the cages for marketing during 1995-96. Numbers above bars are monthly sample sizes

It may be maintained that we are witnessing a peak in a long-term cycle of a naturally occurring endemic disease. Such a hypothesis, however, is not supported by the lack of historical evidence of the disease from the local rabbitfish, which are evidently highly susceptible to the disease. In fact, extensive studies on parasitic infections and diseases of rabbitfish were carried out during the 1970s and 1980s (Paperna 1972, Paperna et al. 1984, Diamant \& Paperna 1985, 1986, 1989 , 1992, Diamant \& Wilbert 1985, Diamant 1989) but no such disease was ever detected. Accordingly, this and the lack of records of the disease from the Red Sea prior to the regional establishment of mariculture are puzzling. It is possible, however, that the pathogen went undetected due to its natural low infection level, which increased dramatically when a highly susceptible host (cultured Dicentrarchus labrax) was made available in large quantities. The only other interpretation of the available data is that Mycobacterium marinum is a recent introduction to the Red Sea.

The molecular identities of the Mycobacterium marinum isolates obtained from the rabbitfish caught at the different sampling sites as well as at the cage-cultured fish indicate that they share a common origin. The 2 net-cage mariculture farms that held infected sea bass (and later red drum) may have acted as a key pointsource for the initial increase in disease levels, and may still act as a focus of dispersal. This hypothesis is supported by the occurrence of infections in 9 of 14 species of wild fish sampled from around the mariculture cages, but not at the coral reef site (see Table 1).

Histological determination of mycobacteriosis prevalence must be regarded as yielding underestimated values, since low intensity infections (i.e. few granulomata per spleen) may go undetected. Thus, actual 

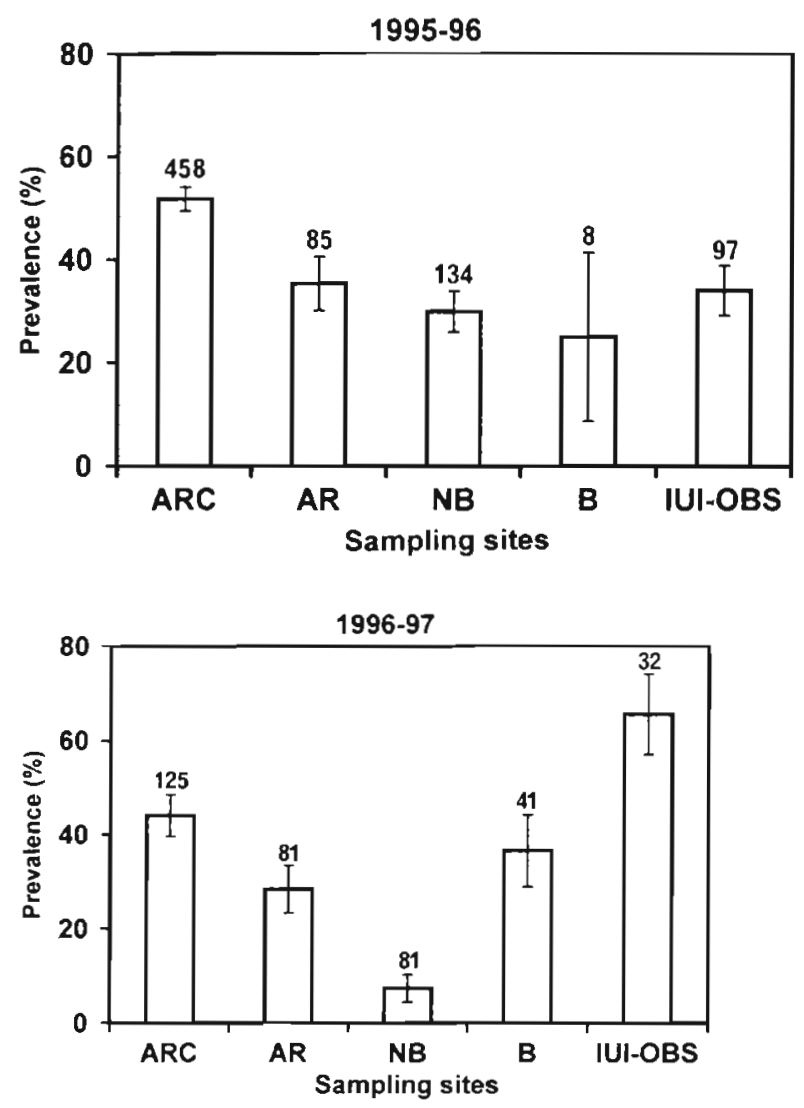

Fig. 6. Comparison of Mycobacterium marinum mean prevalence of infection in Siganus rivulatus between years and between sites, as reflected by splenic granulomata containing acid-fast bacteria (Kruskal-Wallis ANOVAVTukey-Kramer multiple test for unequal samples). Comparison between years: 1995-96 versus 1996-97; $\mathrm{ARC}, \mathrm{n}=583, \mathrm{p}>0.05$, (ns); $\mathrm{AR}, \mathrm{n}=$ 166, $p>0.05$. (ns); NB, $p<0.05 ; B, n=49, p>0.05$ (ns); IUIOBS, $\mathrm{n}=129, \mathrm{p}<0.01$. Comparison between sites during 1995-96 (above): ARC - rabbitfish sampled inside the mariculture cages, $\Omega=458$; AR - rabbitfish sampled from schools surrounding the mariculture cages, $\mathrm{n}=85 ; \mathrm{NB}-$ North Beach sampling site, $n=134 ; B$ - Eilat harbour area; $n=8$; IUI-OBS Coral Reef sampling site, $\mathrm{n}=97$; ARC $>A R$, IUI-OBS, NB $(\mathrm{p}<$ $0.05)$; Comparison between the sites during 1996-97 (below) ARC, $n=125 ; A R-n=81 ; N B, n=81 ; B, n=41 ;$ IUI-OBS $\mathrm{n}=32$ i ARC, IUI-OBS $>B, A R>N B(p<0.05)$ prevalence levels in the studied sites are probably higher than those recorded.

The results suggest that the prevalence of Mycobacterium marinum infection in Siganus rivulatus increases significantly with fish age. This is in agreement with other studies, which have reported age-related infection trends that may emanate from feeding habits, and changes in the habitat with growth or prolonged exposure to infection in older individuals: mycobacteriosis in Atlantic mackerel Scomber scombrus (MacKenzie 1988), Ichthyophonus in sea bass Dicentrarchus labrax and in herring Clupea harengus (Sitja-Bobadilla \& Alvarez-Pellitero 1990, Patterson 1996). Acanthocephalan Sclerocollum rubrimaris abundance in wild rabbitfish $S$. rivulatus in Eilat has also been correlated with host age (Diamant 1989).

A consistently higher Mycobacterium marinum infection prevalence was evident in the rabbitfish samples caught inside the cages in comparison to those caught elsewhere, and this pattern persisted throughout the study. A gradient of decrease in prevalence is evident when the sampling sites are viewed from north to south: cages $>$ cage surroundings $>$ North Beach > Eilat harbour. Such a pattern can be explained if the northernmost site is the point-source of dissemination. However, prevalence values at the coral reef site IUI-OBS, which is south of the sampling sites, do not fit this north-south trend. At IUI-OBS, in fact, prevalence values that were $34 \%$ in 1995-96, nearly doubled to $66 \%$ in $1996-97$. As a result, the mean prevalence values were lowest at North Beach and highest at the mariculture cages and IUI-OBS in 1996-1997. The relatively low prevalence levels at North Beach may be explained by the high proportion of small sized fish at this site (i.e. young, $<160 \mathrm{~mm}$ FL), fish that are less likely to display infections (see Fig. 4). At the same time, a high prevalence at the coral reef site may be due to the high proportion of mature fish (>220 mm FL). However, there is another possible cause: the effect of effluents from the nearby Coral World public aquarium, where outbreaks of

\begin{tabular}{|c|c|c|}
\hline & 71 & 81 \\
\hline I & CTT.CGGAGAT & ACTCGAGTGG \\
\hline II & 1111111110 & $11111: 1111$ \\
\hline I I I & 1111111110 & 1111111111 \\
\hline IV & 1111111110 & 1111111111 \\
\hline
\end{tabular}

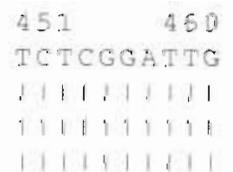
$461 \quad 470$
ACGGTAGGTG

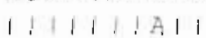
$11111 \mid 1$ A. I
$1|1|$ | | A. I I

1 - rDNA Sequence of Mycobacterium marinum (Rogall et al. 1990)

II - rDNA Sequence of M. marinum from maricultured D. labrax (\#DL240490) Knibb et al. (1993)

III - M. marinum isolate from Siganus rivulatus caught at Eilat harbour (\#NASR300397)

IV - M. marinum isolate from S. rivulatus caught at the coral reef site IUI-OBS near the Interuniversity Institute (\#SR030597)

Fig. 7. 16S DNA (rDNA) sequences of 2 Mycobacterium marinum isolates from wild rabbitfish Siganus rivulatus (III, caught at Eilat harbour [\#NASR300397]; IV, caught at the coral reef site IUI-OBS near the Interuniversity Institute [\#5R030597]) compared with the isolate from sea bass Dicentrarchus labrax (II, [\#DL240490]) in Eilat sequenced by Knibb et al. (1993). The Israeli isolates differ from the $M$. marinum sequence (I) of Rogall et al. (1990) in 2 base pairs 
mycobacteriosis have been repeatedly diagnosed in captive ornamental fish (Colorni et al. 1996) and hawksbill sea turtles (A. Diamant unpubl. data). The oral route of transmission has long been known as principal in the epizootiology of fish mycobacteriosis, and was in fact the reason why the practice of feeding raw, contaminated fish products in salmon hatcheries was stopped (Parisot 1958). Cases of mycobacteriosis at Coral World were suspected to have resulted from feeding displayed fish with Mycobacterium-contaminated fish caught in the mariculture farm area (e.g. Decapterus and Trachurus spp.).

While it has often proven difficult or impossible to provide clear-cut evidence for pathogen transmission between cultured and wild fish, a few cases have been documented which provided strong circumstantial evidence to that effect. In Scotland, case reports of increased infection levels of Myxosoma (Myxobolus) cerebralis and Infectious Pancreatic Necrosis Virus (IPNV) in wild fish near salmon and trout hatcheries and farms have been documented (Yoder 1972, Munro et al. 1976), and heavy Diphyllobothrium spp. infestations of local wild salmon populations were recorded after the establishment of an aquaculture site (Matheson 1979). The monogenean Gyrodactylus salaris, probably an accidental introduction to Norway, spread rapidly in wild salmon populations in its newly adopted environment (Johnsen \& Jensen 1991). In the Mediterranean coast of Israel, a high prevalence of Myxidium leei (Myxosporea) and Mycobacterium marinum infections were recorded in wild grey mullet caught in the vicinity of mariculture farms, but not at other sites sampled along the shore (Diamant \& Paperna 1995, Paperna in press).

Sixty-two coastal fish species have been recorded at North Beach, Eilat, just inshore of the mariculture farms (Golani 1993). Many of these species utilize the area as a natural nursery ground, among them the rabbitfish Siganus rivulatus. As they mature, rabbitfish abound on sandy bottom, sea grass meadows and coral reefs (Fishelson 1977. Diamant 1989). Long-shore movement of rabbitfish schools and predation of infected rabbitfish by piscivores may facilitate dissemination of the mycobacteria, linking the disease with the food web. It is relevant to note that trans-ovarian transmission of piscine mycobacteria (see Chinabut et al. 1994) is an additional potential route of dissemination of this disease.

Dissemination of this fish pathogen may have zoonotic implications, since some mycobacteria have been shown to survive in seawater for long periods (Jamieson et al. 1976), and Mycobacterium marinum has been implicated in sub-cutaneous as well as other lesions in human patients (Collins et al. 1985, Harris et al. 1991, Vazquez \& Sobel 1992).
In the salmon culture industry, the transfer of disease between farmed and wild fish has been regarded as possibly the greatest and most serious consequence of interactions between aquaculture and the environment, with the ultimate goal of fish farming, according to some authors, being to totally prevent any contact between wild and farmed fish (Bergan et al. 1991, Egidius et al. 1991). The results of the present study strongly support the view that mariculture ventures must be preceded by appropriate risk analyses to try and predict possible interactions and disease transfer between the farmed fish stocks and local fish populations (McVicar 1997b).

Despite intensifying environmental impact and conflicts amongst users, the northern Red Sea is still considered one of the few remaining unpolluted tropical marine environments in the Northern Hemisphere. Although poorly planned coastal development, largescale tourism, declining water quality and uncoordinated management are recognized as the major causes of degradation in this region (Fishelson 1995, Maroz \& Fishelson 1997, Golani \& Diamant 1999), net-cage mariculture may be an additional contributing factor to the ongoing deterioration of the marine environment of this landlocked sea, and its impact must be continuously monitored.

Acknowledgements. We thank Dr Avi Baranes, Director of The InterUniversity Institute of Marine Science. Eilat, Gai Ayalon and the staff of Coral World Underwater Observatory and Aquarium, Ezri Alon, Noam Meshi, Avi Gedalya and Dudu Zakai of Coral Beach Nature Reserve, as well as the staff of Ardag and Dag Suf Mariculture Farms for their collaboration and help in obtaining fish samples. The assistance, during various stages of this study, of Nathan Wajsbrot, Sharona Turkia, Yariv Shtupler, Barbara Colorni and Tamara Livshits, all of NCM, is gratefully acknowledged. This research was supported by the Israel Ministry of National Infrastructures and the German-Israel BMBF MARS-1 project, contract 03F0159B, coordinated by GKSS Geesthacht and the Ministry of Sciences and Arts, Israel, and carried out at the Green-Keiser Fish Health Center, NCM, IOLR Eilat.

\section{LITERATURE CITED}

Aure J, Stigebrandt A (1990) Quantitative estimates of the eutrophication effects of fish farming on fjords. Aquaculture 90:135-156

Belas R, Faloon P, Hannaford A (1995) Potential applications of molecular biology to the study of fish mycobacteriosis. Annu Rev Fish Dis 5:133-173

Bergan PI, Gausen D, Hansen, LP (1991) Attempts to reduce the impact of reared Atlantic salmon on wild in Norway. Aquaculture 98:319-324

Carss DN (1990) Concentrations of wild and escaped fishes immediately adjacent to fish farm cages. Aquaculture 90: $29-40$

Chinabut S, Kanayati Y, Pungkachonboon T (1994) Study of transovarian transmission of mycobacteria in Betta splen- 
dens Regan. In: Chou LM and 10 authors (eds) Proceedings of the 3rd Asian Fisheries Forum. Asian Fisheries Society, Manila, Philippines, p. 339-341

Collins C, Grange J, Noble W (1985) Mycobactenum marinum infections in man. J Hyg 94:135-149

Colorni A (1992) A systemic mycobacteriosis in the European sea bass Dicentrarchus labrax cultured in Eilat (Red Sea). Bamidgeh - Isr J Aquacult 44:75-81

Colorni A, Ucko M, Knibb W (1996) Epizootiology of Mycobacterium spp. in seabass, seabream and other commercial fish. In: Seabass and seabream culture: problems and prospects, handbook of contributions. Verona, Italy, Oct 16-18, 1996. Eur Aquacult Soc Spec Publ, p 259-261

Colorni A, Avtalion R, Knibb W, Berger E, Colorni B, Timan B (1998) Histopathology of sea bass (Dicentrarchus labrax) experimentally infected with Mycobacterium marinum and treated with streptomycin and garlic (Allium sativum) extract. Aquaculture 160:1-17

Coutant CC (1998) What is 'normative' for fish pathogens? A perspective on the controversy over interactions between wild and cultured fish. J Aquat Anim Health 10:101-106

Diamant A (1989) Ecology of the acanthocephalan Sclerocollum rubrimaris Schmidt \& Paperna 1978 (Rhadinorhynchidae: Gorgorhynchinae) from wild populations of rabbitfish (genus Siganus) in the northern Red Sea. J Fish Biol 34:387-398

Diamant A, Colorni A (1995) Net-pen mariculture: a potential source of dispersal of Mycobacterium to native fish. European Association of Fish Pathologists, Seventh International Conference, Palma de Mallorca, Sept 1995, p 66 (Abstract)

Diamant A, Paperna I (1985) The development and ultrastructure of Nosema ceratomyxae sp. nov. (Microsporidae), a hyperparasite of the myxosporean Ceratomyxa sp. from siganid fishes in the Red Sea. Protistologica 21:249-258

Diamant A, Paperna I (1986) The parasites of wild Red Sea rabbitfish Siganus spp. (Pisces: Siganidae) as potential pathogens in mariculture. In: Vivares $C P$, Bonami JR, Jaspers $E$ (eds) Pathology in marine aquaculture. Eur Aquacult Soc Spec Publ No. 9, Bredene, Belgium, p 71-83

Diamant A, Paperna I (1989) Cytopathology of Ceratomyxa sp. (Myxosporea) hyperparasitized by the microsporidan Nosema ceratomyxae. Dis Aquat Org 6:75-79

Diamant A, Paperna I (1992) Zschokkella icterica sp. nov. (Myxozoa, Myxosporea) a pathogen of wild rabbitfish Siganus luridus (Ruppell, 1829) from the Red Sea. Eur J Protistol 28:71-79

Diamant A, Paperna I (1995) Protozoan diseases of fish in Mediterranean marine aquaculture. The Second European Congress of Protistology and Eighth European Conference on Ciliate Biology, July 21-26, Clermont Ferrand, France. Eur J Protistol 31:402-476

Diamant A, Wilbert $N$ (1985) Balantidium sigani sp. nov., a trichostome ciliate from Red Sea rabbitfish (Pisces: Siganidae). Arch Protistenk 129:13-17

Diamant A, Banet A, Paperna I, von Westernhagen H, Broeg K, Kruener G, Koerting W, Zander S (1999) The use of fish metabolic, pathological and parasitological indices in pollution monitoring. II. Red Sea and Mediterranean. Helgol Mar Res 53(3/4): 195-208

Egidius E, Braaten B, Andersen K, Gokstad S, Lohne S (1983) Vibriosis in saithe (Pollachius virens) populations of the Norwegians coast. Rapp PV Réun Cons Int Explor Mer 182:103-105

Egidius E, Hansen LP, Jonsson B, Naevdal G (1991) Mutual impact of wild and cultured Atlantic salmon in Norway $\mathrm{J}$ Cons Int Explor Mer 47:404-410
Fishelson L (1977) Sociobiology and feeding behaviour of coral fish along the coral reef of the Gulf of Eilat (=Gulf of Aqaba), Red Sea. Isr J Zool 26:114-134

Fishelson L (1995) Elat (Gulf of Agaba) littoral: life on the red line of biodegradation. Isr J Zool 41:43-55

Golani D (1993) The sandy shore of the Red Sea-launching pad for Lessepsian (Suez Canal) migrant fish colonizers of the eastern Mediterranean. J Biogeog 20:579-585

Golani D, Diamant A (1999) Analysis of the colonization patterns of a fish community of a small artificial reef in the Gulf of Eilat, northern Red Sea. Environ Biol Fish $54: 275-282$

Gonzalez L (1998) The life cycle of Hysterothylacium aduncum (Nematoda: Anisakidae) in Chilean marine farms. Aquaculture 162:173-186

Gowen RJ, Bradbury NB (1987) The ecological impact of salmonid farming in coastal waters: a review. Oceanogr Mar Biol 25:563-575

Harris L, Striplin W, Burnside R (1991) Aquatic hazard of Mycobacterium marinum infection. Ala Med 61:8-10

Iwama $G$ (1991) Interactions between aquaculture and the environment. Crit Rev Environ Control 21:177-216

Jamieson W. Madri P, Claus G (1976) Survival of certain pathogenic organisms in seawater. Hydrobiologia 50: $117-121$

Johnsen OJ, Jensen AJ (1991) The Gyrodactylus story in Norway. Aquacult 98:289-302

Kent ML (1994) The impact of diseases of pen-reared salmonids on coastal marine environments. In: Ervik A, Hansen PK, Wennevik V (eds) Proceedings of the CanadaNorway workshop on environmental impacts of aquaculture, 8-10 Feb 1993. Havforskningsinstituttet No. 13, p $85-95$

Kent ML, Traxler GS, Kieser D, Richard J, Dawe SC, Shaw RW, Prosperi-Porta G, Ketcheson J, Evelyn TPT (1998) Survey of salmonid pathogens in ocean-caught fishes in British Columbia, Canada. J Aquat Anim Health 10: 211-219

Kissil GW (1996) Aquaculture in Israel. World Aquacult 27: 25-30

Knibb W, Colorni A, Ankaoua M, Lindell D, Diamant A, Gordin H (1993) Detection and identification of a pathogenic marine mycobacterium from the European sea bass Dicentrarchus labrax using polymerase chain reaction and direct sequencing of $16 \mathrm{~s}$ rDNA sequences. Mol Mar Biol Biotechnol 2:225-232

Mackenzie K (1988) Presumptive mycobacteriosis in NorthEast Atlantic mackerel, Scomber scombrus L. J Fish Biol $32: 26-275$

Maroz A, Fishelson L (1997) Juvenile production of Amphiprion bicinctus (Pomacentridae, Teleostei) and rehabilitation of impoverished habitats. Mar Ecol Prog Ser 151. 295-297

Matheson A (1979) An investigation of the occurrence of plerocercoids of Diphyllobothrium spp. in farmed Atlantic salmon. MSc thesis, University of Stirling, Scotland

McArdle JF, Dooley-Martin C, Georghegan F, McKiernan F, Rodger $H$ (1993) Furunculosis as a possible factor in the decline of sea trout in the west of Ireland. Fish Res 17: 201-207

McVicar AH (1975) Infection of plaice Pleuronectes platessa L. with Glugea (Nosema) stephani (Hagenmuller, 1899) (Protozoa: Microsporidia) in a fish farm and under experimental conditions. J Fish Biol 7:611-619

McVicar AH (1997a) Interaction of pathogens in aquaculture with wild fish populations. Bull Eur Assoc Fish Pathol 17: $197-200$ 
McVicar AH (1997b) Diseases and parasite implications of the coexistence of wild and cultured Atlantic salmon populations. ICES J Mar Sci 54:1093-1103

Mires D (1997) Trends of fish consumption in Israel and their impact on aquaculture production strategies. Isr J Aquacult 49:145-150

Munro ALS, Liversidge J, Elson KGR (1976) The distribution and prevalence of infectious pancreatic necrosis virus in wild fish in Loch Awe. Proc R Soc Edinb 75:223-232

Munro ALS, McVicar AH, Jones R (1983) The epidemiology of infectious disease in commercially important wild marine fish. Rapp PV Cons Int Explor Mer 182:21-32

Paperna I (1972) Parasitological implications of fish migration through interoceanic canals. 17 th Congr Int Zool (Monte Carlo, Sept. 1972). Thème No. 3: Les conséquences biologiques des canaux inter-oceans, p 1-9

Paperna I (in press) Mariculture versus environment: risks and impacts. Bio Mar Medit

Paperna I, Diamant A, Overstreet RM (1984) Monogenean infection and mortality in wild and cultured Red Sea fishes. Helgol Meeresunters 37:445-462

Parisot $T$ (1958) Tuberculosis in fish: a review of the literature with a description of the disease in salmonid fish. Bacteriol Rev 22:240-245

Patterson KR (1996) Modeling the impact of disease induced mortality in an exploited population: the outbreak of the fungal parasite Ichthyophonus hofer in the North Sea herring (Clupea harengus). Can J Fish Aquat Sci 53: $2870-2887$

Popper D (1995) Expected impact of cage culture in the Gulf of Eilat. In: Proceedings of the Ecosystem of the Gulf of Aqaba in Relation to the Enhanced Economical Development and the Peace Process - II. The Interuniversity Institute for Marine Sciences in Eilat, January

Editorial responsibility: David Bruno,

Aberdeen, Scotland, UK
30-February 2, p 72-77

Porter CB, Krost P, Gordin H, Angel DL (1996) Preliminary assessment of grey mullet (Mugil cephalus) as a forager of organically enriched sediments below marine fish farms. Isr J Aquacult 48:47-55

Rogall T, Flohr T, Boettger EC (1990) Differentiation of $M y c o-$ bacterium species by direct sequencing of amplified DNA J Gen Microbiol 136:1915-1920

Silan P, Cabral P, Maillard C (1985) Enlargement of the host range of Polylabris tubicirrus (Monogenea, Polyopisthocotylea) under fish-farming conditions. Aquaculture 47: $267-270$

Sitja-Babadilla A, Alvarez-Pellitero P (1990) First report of Ichthyophonus disease in wild and cultured sea bass Dicentarchus labrax from the Spanish Mediterranean area. Dis Aquat Org 8:145-150

Stephen C, Kent ML, Dawe SC (1993) Hepatic megalocytosis in wild and farmed chinook salmon Oncorhynchus tshawytcha in British Columbia, Canada. Dis Aquat Org 16: 35-39

Treasurer JW, Cox D (1991) The occurrence of Aeromonas salmonicida in wrasse (Labridae) and implications for Atlantic salmon farming. Bull Eur Assoc Fish Pathol 11: 208-210

Treasurer JW, Laidler LA (1994) Aeromonas salmonicida infection in wrasse (Labridae), used as cleaner fish, on an Atlantic salmon, Salmo salar L., farm. J Fish Dis 17: $155-161$

Vazquez J, Sobel J (1992) a case of disseminated Mycobacterium marinum infection in an immunocompetent patient. Eur J Clin Microbiol Infect Dis 11:908-911

Yoder WG (1972) The spread of Myxosoma cerebralis into native trout populations in Michigan. Prog Fish Cult 34: $103-106$

Submitted: May 6, 1999; Accepted: October 13, 1999

Proofs received from author(s): January 24, 2000 